\title{
On the Competition Programme of the 31st Moscow IFF
}

\author{
By Christina Stojanova
}

Fall 2009 Issue of KINEMA

\section{CHARACTERS AND CIRCUMSTANCES: NOTES ON THE COMPETITION PRO- GRAMME OF THE 31st MOSCOW IFF}

If a common aesthetic denominator of the competition films, presented at the 31st Moscow International Film Festival (June 19-28, 2009) is to be found, it would be the predominance of mythos (plot) over ethos (character). While most of the characters were ordinary people - that is, "responding to our sense of common humanity" and like us not distinguished by "superior power of action and intelligence" - the extraordinary circumstances were removed either in time, space or in degree from "the cannons of probability that we would find in our own daily experience" (See Frye). In other words, the Moscow competition films were, as Aristotle would have it, about the predominance of the plot, the soul of the play, and stood or fell upon its intricacies, overshadowing the particular psychological and moral make-up of its dramatis personae. Whether good or bad, they suffered more as a consequence of an act or happenstance outside of them: usually defined as destiny or fate in ancient Greek plays and romantic (melo) drama, and in modern times as historical inevitability or social determinism.

The sense of entrapment in these films was additionally enhanced by the prevalent arrangement of the incidents as a guest of sorts, usually leading nowhere and leaving the protagonists either dead or much worse off.

As is to be expected in this line of thought, the most intriguing films in competition were Russian (Aleksandr Proshkin's Miracle/Chudo; Nikolai Dostal's Petya On The Way to Heaven/ Petya po doroge v tsarstvie nebesnoe), or in Russian (Kira Muratova's FIPRESCI winner Melody for a Barrel-Organ (Melodiya dlya sharmanki), made in Ukraine. These three highly awarded films were closely followed by strong works, made in Georgia (Mediator/ Mediatori, dir. Dito Tsintsadze, co-produced with Germany), in Hungary (Prank/ Tréfa, dir. Péter Gárdos); in Bulgaria (Crayfish/Raci, dir. Ivan Tscherkelov) and in Poland (Little Moscow/ Mala Moskwa, dir. Waldemar Krzystek). The fact that the youngest post-Communist directors in competition were born in 1957 points to the fact that, after nearly half a century of totalitarian rule and twenty years of misguided reforms, the filmmakers from the former Soviet bloc countries have become proven experts in prioritising mythos over ethos, i.e., in interpreting the actions and motivations of their characters as an intrinsic result of overbearing sociopolitical pressures.

Certainly, the Iranian film Bibi (dir. Hassan Yektapanah), the Israeli Burning Mooki (Mooki bo'era, dir. Lena Chaplin and Slava Chaplin) and the Italian As God Commands (Come Dio comanda, dir. Gabriele Salvatores) stood their ground both professionally and artistically as original variations of the same aesthetic approach, featuring characters emasculated by unforgiving social and political forces, roughing up their lives. Even the least interesting films (from Japan, Korea and especially from the United States) played up the role of historical and social circumstance at the expense of their characters' psychological make up or free will.

\section{The Three Major Films}

\section{Miracle (Chudo)}

One of the competition favourites, the Russian Miracle, could be reviewed as a paradigmatic example of the aesthetic features, mentioned above. Set in the faithful days around the Soviet Communist Party $20^{\text {th }}$ Congress in 1956 and Khrushchev's secret speech exposing Stalin's atrocities, it tells the unusual story of a girl named Zoya and is based on an allegedly authentic occurrence in the town of Samara (former Kuybishev), known as the "Standing of Zoya". A handsome factory worker (Polina Kutepova), a loyal member of the Young Communist League (or the Komsomol) and a militant atheist who forces her mother to take all the icons off the walls and to the local church, she turns into a motionless statue after attempting a sacrilegious dance during the Christmas lent with the icon of St. Nicholas - the only one left behind - known by Christian Orthodox believers as the Miracle-Maker. This event has a ghastly ripple effect, causing death and major disturbance throughout the seedy industrial settlement, throwing the Party and the KGB into a deep crisis, 
and revealing in the process their unholy alliances with the clergy and the media. Four months later, around Easter-time, the crisis gets suddenly resolved in a truly deus ex machina style by Chairman Khrushchev himself when his personal plane makes an emergency landing in the area. Following a higher clergy's advice, the Chairman's officials find a 'male virgin', the only one capable of bringing Zoya back to life by wiggling the icon out of her hands. However, since during her standing she has herself turned into a passionate believer and a miracle-maker, Zoya is sent to a mental hospital as a precaution against any further spreading of 'Christian superstition', thus marking symbolically the limits of Khrushchev's liberalism.

Even such a snapshot of the elaborate novelistic narrative makes transparent the compelling social and political allusions of this skillful rendition of "Zoya's Standing" by Yuri Arabov, one of the most versatile Russian scriptwriters [and writer of such renowned works as A. Sokurov's Moloch (1999), Taurus (2001), Sun (2005); K. Serebrennikov's Yuri's Day (2008), etc]. In his turn, the director presents Zoya's ordeal as a straightforward - superbly acted and visualized - parable of the dramatic fate of Russian spirituality (or the Russian soul) under Communism. First held into stupefying bondage by Stalinist crash-modernization and atheism, then briefly released by Khrushchev's thaw, only to be confined to a mental hospital, which, until Perestroika, would successfully replace the Stalinist Gulag as a means of containing freedom.

However, as in any allegorical discourse, double entendre is the name of the game: on one hand, the miraculous event takes a life of its own, triggering a chain of unusual occurrences and coincidences. On the other hand, however - not unlike Khrushchev's proverbial 'liberalization' - the miracle sets off a major exercise in ideological hypocrisy where the state manages to have it both ways: to keep it under a tight control and to also use it as a means of distraction from the serious social and economic problems of the day. This complex plot dynamics divides the characters not in heroes and villains, but in candid believers and manipulative cynics, or - to use the already forgotten discourse of the day - into dissidents and authorities, or 'us' and 'them'. The infamous slyness of the latter serves as a narrative motor, epitomized by the KGB agent (Sergei Makovetsky). A perfidious agent-provocateur, his task is to curb and derail the local priest and the regional journalist in their attempts to interpret the miracle according to their conscience and faith. While his demonic allure is deliberately sabotaged by the sardonically handled artificial eye -a symbol of his dubious vigilance - and Makovetsky's over-the-top acting style, Khrushchev's lame impersonation undermines further - and quite spontaneously at that -the myth of the Great Trailblazer of Liberalization.

By hook or by crook, the cynics in power put to a severe test the resilience of the believers (or the dissidents) to act as moral and rational agents vis-a-vis the miracle. Thus the theological ambiguity of Zoya's suffering - the Orthodox church does not generally sanction belief in miracles, involving lay individuals - becomes as an essential staple of the agent's strategy to destroy the devout local priest. It turns him if not into a cynic than into a tragic disbeliever, who hastily gives up on his church, his family and his confused teenage son. The son bears out the weakness of his father's faith by joining the Communist militia (police-force). And it is this priest's son-turned-police cadet who becomes the 'male virgin' to break Zoya's spell in yet another transparent parable of the short-lived miracle of Khrushchev's thaw and the way (or rather by whom) it was brought to an end.

The KGB agent's active tampering with what the regional journalist Nikolai (Konstantin Khabensky) believes to be his noble quest for the truth of Zoya's Standing shakes this philandering and somewhat spoilt newsmaker out of his self-delusional complacency. It forces him to realize his true cynical nature, disguised as that of a believer. After all, it was him that Zoya was waiting for before impatiently grabbing St Nicholas's - his namesake's - icon for her ill-fated dance. After the spiritual demise of the priest and the journalist, the only successful quest for the truth - most likely due to its divine serendipity - is that of Zoya herself, and therefore her transformation of a cynic into believer is most severely punished.

\section{Melody for a Barrel-Organ (Melodiya dlya sharmanki)}

The FIPRESCI winner, Melody for a Barrel-Organ (Pesnya dlja sharmanki, 2008) by Kira Muratova, the veteran enfant terrible of the Ukrainian and Russian/ Soviet cinema, is yet another baroque winter tale, this time around situated in a contemporary, non-identified post-Soviet city (Kiev?). Structured like a Renaissance picaresque - a satiric quest with a moral message but with a tragic twist - it features two orphaned children as the impoverished rascals or the picaros and their doomed voyage through a corrupt society. 
Following the death of their mother, pre-teens Nikita and Aliona - in an attempt to avoid being sent to different orphanages by the soulless Social Services - embark on a search for their long-gone respective fathers. It is Christmas time and cold, and the two far from picture-perfect children (sickishly pale and somewhat overweight) are on their own in the world of post-Soviet capitalism, whose savage reality is ever so slightly but very effectively suspended for the film. The archetypal symbols of modern speed and greed - a railway station, a casino and a supermarket - are therefore ominously defamiliarized by the tight frame composition, and the perennially drifting artificial snow, along with the grotesque exaggeration of characters and acting, enhance their disconcerting effect.

The story is loosely reminiscent of the Russian fairy tale about the orphaned Little Sister Alyonushka and Little Brother Ivanushka stalled on their solitary road to living happily ever after, first by Ivanushka's impatience - he turns into a kiddie-goat after drinking water from a goat's hoof-mark despite Alyonushka's passionate warnings - and then, when happiness seems to be quite at hand what with Alyonushka's marriage to a rich merchant - by a wicked witch who tries to kill them both. Finally, thanks to the timely intervention of a loyal servant, who exposes the witch's designs, Ivanushka turns back into a happy boy and the drowned Alyonushka is resuscitated as even happier and prettier bride to her merchant.

While Vladimir Zuev's script has dispensed with the miraculous occurrences and the happy ending, it is obviously greatly indebted to Alyonushka's (diminutive of Aliona) self-sacrificial sisterly love, eternalized by the famous painting Alyonushka (1881) by Viktor Vasnetsov. There is a rich, obviously nouveau rich Merchant (Oleg Tabakov) in Muratova's film as well, but he appears toward the finale as a not very effectual saviour: despite of his intellectual softness and amicability, he is equally excited over buying a brand leather bag as he is about saving the hungry and cold Nikita, whom he finds huddled against the doors of the posh supermarket. The Merchant-saviour is however in a hurry to catch a plane and has no time to hear Nikita's confused story about their voyage and most importantly, his worries about his sister, who has been gone for so long inside the store in search of food. The Merchant also happens to be married to the Witch (Renata Litvinova), who is actually very beautiful and not wicked at all, and does come to the supermarket to take Nikita home. Self-consciously decked for the occasion in her diamond tiara and expensive fur cape, she however is too impatient to look for the boy who has just been kicked out by some zealous security guard, and ends up doing some Christmas shopping instead....

As a matter of fact, none of the people the children encounter in their macabre quest are really wicked, but just preoccupied with pursuing the good life - blabbing on cell phones, sleeping in luxury lounges, eating, but mostly spending money in casinos and supermarkets - to really notice the two destitute children. And those who do notice them are either, like the nouveau rich couple, too good to be true, or too real to be good, like the woman who disappears with the five-hundred Euro banknote they have accidentally found... Or too harsh, like overzealous supermarket managers, who daunt Alyona for stealing food for her starving brother. In the end, while Alyona's misfortune is being sealed by criminal charges, little Nikita dies of exposure in the attic of a house under reconstruction just hours before being discovered by the contractors, whose foreman appears to be Alyona's missing father...

Like in every Christmas tale, salvation through a happy coincidence seems always within a reach, but as in the classical 19th century melodrama is somehow always put off by bad timing or bad communication. Maybe in an attempt to make up for this endemic injustice and demonstrate that the most important things in life are often lost in the details we have no patience for, Muratova's narrative is usually very detailed and its pace - deliberately slow... Obviously this is her way of making us engage with the tragic story evolving on screen. If not as citizens then at least as compassionate and thoughtful viewers and listeners...

\section{Petya on The Way to Heaven (Petya po doroge $v$ tsarstvie nebesnoe)}

The eponymous quest of Petya "on his way to Heaven" is an exercise in the much touted post-modern irony in presenting an important event from the unusual perspective of the village fool. Not unlike Tom Stoppard's Rosencrantz 83 Guildenstern Are Dead, the celebrated interpretation of Hamlet from the point of view of two secondary characters standing in the wings, thus changing the mode of Shakespeare's original from tragic to darkly ironic. In spite of the title, there is no quest per se in Dostal's film, where Petya (Egor Pavlov), a handsome young man with the looks of a movie star and the intelligence of a five year old, goes about his weird daily routine of imagining himself to be the traffic controller of the remote Siberian town of 
Kandalaksha - a game everyone around happily joins in, until one day, mistaken for a forced-labour camp fugitive, he is accidentally shot to death. And there is no explicit message to boot this pseudo-quest either, as the film offers an unexpectedly rosy-cheeked picture of the town, whose inhabitants are predominantly KGB personnel and other employees of the newly built Gulag camp.

The story takes place in the fateful days before and after Stalin's death on March 5, 1953 but its timing does not seem to deeply affect the action. The fleeting references to a number of serious, even tragic social and political issues that have otherwise deeply marked this era are offered in a deliberately non-engaging manner. The virulent anti-Semitism, triggered by the on-going trial against Stalin's 'conniving' doctors; the election travesty where people choose 'freely' one candidate, appointed from above; the nascent nuclear program, based on forced labour; the ongoing bias against 'bourgeois elements' and persecution of 'enemies of the people' as well as the abject poverty and alcoholism, are casually interwoven into a deceitfully normalized backdrop, where even the newly-arrived Gulag prisoners seem quite content. As a result, the society looks as homogeneous and united as a Socialist Realist poster from the period, with auspicious historical tensions removed from the almost plot-less narrative.

In the seemingly random selection of serene episodes, even Petya's presence becomes non-essential as the focus is shifted to other, more intriguing personages and their fascinating activities: the KGB colonel, his gorgeous wife, who also happens to be a doctor, and her current lover, a handsome Jewish colleague. However, in a typically Dostalian manner, while we hear his virtuoso piano playing, we hardly get a glimpse of her prospective lover, the newly arrived engineer. Preoccupied with their privileged life of lavish parties, sex, jealousy and infidelity, these 'secondary' personages seem as disastrously oblivious to the enfolding depravity as the challenged Petya ...

Dostal's style however relies heavily on the viewer's ability to imagine the untold - and deliberately unseen dark side of this sun-lit idyll, and to draw the necessary conclusions from the sharp contrast. Unfortunately, his sophisticated tongue-in-cheek sarcasm, targeting human complacency, propensity for self-delusion and conformity to any and all circumstances - which ultimately cause the death of Petya, the film's only innocent soul - might be lost on viewers without preliminary knowledge of the tragic intricacies of Soviet history.

\section{Against the Intricacies of East European History}

The competition films from the other post-Communist countries presented a variety of emasculated characters up against overwhelmingly hostile circumstances and evil protagonists - historical as well as contemporary - uncannily similar to those discussed above. With its propensity to resolve grave social tensions onto the private terrain of home and family, melodrama remains the most effective vehicle for displaying the destructive, even murderous stand off between the individual and his overwhelming environment.

\section{Little Moscow (Mala Moskva)}

The Polish melodrama Little Moscow tackles age-old tensions between Russia as historical usurper and Poland as a perennial victim of its imperial appetites, and mediates it through the impossible love affair of a Russian officer's wife and a Polish officer. As is to be expected, the chain of tragic coincidences, shaping their misfortunes, is set in motion by the KGB, the strictest custodian of the Soviet state interests and those of its military contingent, stationed on the 'fraternal' Polish soil. Obviously, 'national security' considerations override far and wide the individual rights of the two lovers to live and have a child together, and even those of the cuckolded husband, willing to let his beloved wife go. Yet when she tenaciously refuses to comply with the KGB representative's 'advice' to surrender her love in the name of her country, all hell breaks loose as the authorities fear an unwarranted precedent.

Following the logic of the genre, the destinies of the three main characters (by the way, gorgeous looking) are sealed by bad timing and frustrated communications due to the Warsaw pact invasion of Czechoslovakia in 1968. And although some forty years later the cause of the woman's death (a KGB inspired and executed assassination) remains suspected suicide, her daughter - thanks to the noble upbringing of the self-sacrificial Russian husband - finds strength to honour her mother's passion by forgiving her and by reconciling with her real Polish father.

Prank (Tréfa)

In the exquisitely visualized Prank (cinematographer László Seregi), a group of rebellious teen-age boys of a 
private Austro-Hungarian Catholic school try to negotiate their individual rights and freedoms in a similarly restricted and repressive environment but their timid attempts at bildungs-like quests are eventually stifled.

The kids are caught in the crossfire between two opposite pedagogic camps, epitomized by two of their younger tutors: while the 'good' one is an ardent proponent of liberal pedagogic ideas, based on personal freedom and responsibility, it is the 'bad' one - an open supporter of corporal punishment and nasty tactics, pitting the kids against each other - who eventually prevails. Yet, according to the film, the most sinister reason for his notoriety is that his methods are quite in tune with the looming spirit of doom - enhanced by references to the sinking of the Titanic - on the eve of the Great War and the demise of Austro-Hungary. Eerily reminiscent in tenor and the time-setting of Michael Haneke's recent Palme d'Or winner The White Ribbon (Das weisse Band, 2009), implying that the malice of children is the surest sign of pending social depravity, Prank meticulously examines how moral and physical callousness brings out the worst in the students, making them turn against their teachers, each other and ultimately kill the weakest one in their midst.

\section{Through the Post-Communist Wilderness}

On the background of the ensnaring laws of destructive historical determinism, the reasons for the moral and physical ruin of the personages from Crayfish and Mediator are not so clear. Unlike the ill-fated lovers (Little Moscow) and the unredeemable kids (Prank), the characters of these contemporary works succumb willingly to the forces of evil - that is, to the proliferating criminal structures, national and international, and their henchmen.

Set along the fault line of the post-Communist wilderness, stretching from the Caucasus to the Balkans, Crayfish and Mediator are very good examples of two of the most common post-Communist genres - that of the popular "Mafiosi thriller" and the art-house "miserabilism" (Stojanova, 2006).

\section{Mediator (Mediatori)}

In Mediator, the eponymous protagonist is the ex-officio messenger of a vaguely mentioned secret services conglomerate in hot pursuit of a renegade insider, and appears as a deus ex machina only at a few key moments to clarify the otherwise rather intricate plot. The narrative features another half a dozen hardened criminals, foreign and local, as well as members of the Tbilisi police, involved in a Russian-doll-like conspiracy, at the very bottom of which are the Georgians. The only incorrupt soul seems to be the local police inspector, but he is hastily taken off the case by his boss - an obvious accomplice of the mysterious Mediator - under the pretext that he does not speak English. Overall, this skilfully put together narrative reveals a rather diverse portrait of Tbilisi demimonde. The criminal ring leader - the Georgian connection so to speak - is an older expat in charge of a young man and a woman, surprisingly intelligent and good looking, who are allotted the dirtiest job of torture, dangerous conspiracy and messy killings. There is also the ubiquitous Russian prostitute - a genre fixture - accidentally implicated in one of the killings. And then there is the inspector's drug-addicted mistress who also happens to be the ex-wife of the expat, as well as a few other ordinary citizens involved with the action.

As a belated offshoot of the Mafiosi Thriller - on the wane since Aleksei Balabanov's hilarious pastiche Blind Man's Bluff (Zhmurky, 2005) all but wiped the genre he himself successfully propelled in the 1990s with Brother 1 (Brat 1, 1997) - Mediator appears in time of serious economic troubles, political and ethnic instability in Georgia. Unlike Russia and Poland, however, where the Mafiosi Thriller flourished, the former Soviet republic has only recently attracted international attention and made this versatile co-production with Germany viable. Yet while celebrated genre specimens like Balabanov's Brother 1 and Brother 2, the TV mini series Law of the Lawless (Brigada, Aleksei Sidorov, 2002), the Polish Pigs (Psy, Wladislaw Pasikowski, 1992) - to name but a few - did exploit commercially the violence and the blood that go with telling stories about the post-Communist organized crime, they were also concerned with the ethical repercussions this phenomenon posed to their respective post-Communist societies, and therefore introduced lonely vigilante heroes (sometime renegade Mafiosi themselves) as the terrorized society's last hope against the forces of evil.

Mediator, on the other hand - with the post-modern nonchalance of a self-reflexive genre redaction, relying on virtuoso narrative techniques of flashbacks and sophisticated re-interpretation of identical episodes from different points of view - does not even bother with ethical wherewithal. Instead of ruthless Mafiosi, the 
film casts the killers as existential victims of dire circumstances, but fails to explain what those are. Indeed, amongst the graffiti-covered dilapidated pre-fab high-rises, the seedy life in and around the capital is not very attractive for young enterprising people, what with chronic unemployment, criminality, and general ennui that the good life is elsewhere - usually far away from Tbilisi, and westward. But these fall far short of building a solid case on behalf of cold-blooded killers, whose victims all the more are small-time desperados like themselves.

As the only candidate for the role of the handsome lonely hero who saves the day, Mediator presents an archetypal middle-aged loser - the overweight, sexually frustrated police inspector, who does not even speak English (sic) and succumbs to the charms of the Russian prostitute. And unlike his famously non-illustrious counterpart Colombo, he fails to rise to the occasion and carry the day. The film however does introduce a lonely handsome hero, albeit not as a saviour but as a hit man, a-la Alain Delon in Le Samurai (Jean-Pierre Melville, 1967), and tries very hard to construe him as a tragic personage, victim of circumstances wrought by the will of his mighty overseas bosses. Despite his manly intellectual allure, however, the actor (Merab Ninidze) is hard put to convince the audiences that his character is indeed more than just a killer for hire. For no amount of existential angst could compensate the irony that his hamartia (or tragic flaw) seems to be uncompromising greed and selfishness. Hardly redeeming qualities even in the Melville tradition, where the flawed hero at least provokes his own death as the only way out of his messed-up life.

\section{Crayfish (Raci)}

This tendency to present murderous Mafiosi and other good-for-nothing types as either imprudent products of a social accident or dark knights of sorts, is close in tenor to the quintessential feature of 'miserabilism' to never show (let alone analyse) the source of the enfolding evil but only its hideous results. With one major difference: the Mafiosi Thriller targets the winners, 'miserabilism' - their quite tangible victims, the down-and-outs, those unwilling or unable to comply with the laws of the nascent capitalist jungle. In this light, Mediator and Crayfish could be read as hybrids of both genres, with the former cunningly trying to present its accomplished criminals as reluctant wretches, while the latter revels masochistically in the failure of wretches to become successful criminals. Crayfish exposes the mechanism of how Doka and Bonza - otherwise good guys from good families but too lazy, too supercilious or just too inept to find and hold a decent job - fall into the Mafiosi trap.

Crayfish is arguably the only film under scrutiny here, where the incidents (or the plot) are arranged entirely by the evil protagonists over the head of the two principal characters, who are being used by two Mafiosi-turned-businessmen as crayfish-bait (thereby the film's title) in a murderous scheme the mistrustful businessmen cook up to test one another. Boka (Phillip Avramov) is paid by one of them to make a phone call from a moving train to the driver of a red van when in closest proximity, which unbeknownst to him triggers an explosion, killing the driver who happens to be his best friend Bonza (Valeri Yordanov), hired by the other businessman.

In a rare exception to the principles of 'miserabilism' - and to his own - the director depicts with sarcastic gusto the conniving bosses as the source of evil by casting Rangel Vulchanov, one of the best Bulgarian directors from the older generation as the more enterprising of the two. Vulchanov's antics (he is also a versatile comedian) sit well with the tongue-in-cheek apathy of the two rising stars of Bulgarian cinema, enacting the drama of two close friends whose quest for easy money and lack of real rapport ends up in tragedy.

\section{Alone In The Hostile City}

\section{Bibi}

Quite understandably, Bibi - the low-budget Neo-realist story of an elderly Iraqi refugee in Iran and her obsessive pursuit of an ID card for the sole purpose she could be buried one day in a marked grave, which her Iraqi daughter would be able to visit once the war ends - is both generationally and artistically, as well as literally, a world away from the predominantly brooding mood of the films discussed so far, and their intricate metaphors, populated mostly by young, handsome but tormented characters.

Bibi - in the beautifully understated interpretation of Salimeh Rangzan - embarks on her own on an unexpectedly lucid quest for a Muslim woman. Structured as any archetypal voyage through a hostile environment, 
Bibi's devout search for the document through the labyrinth of the heavily bureaucratized Iranian immigration system and the treacherous big city falls in line with Odysseus' travels, Dante's sojourn through hell and purgatory, and especially with Kafka's Joseph K. and his ever pending trial. Her guide in this tedious and humiliating journey, or rather series of futile daily trips, is a young taxi-driver who is humbled into helping Bibi by her unusual determination and resourcefulness but, after being stalked by police informers, ends up arrested and probably killed for trying to get her a forged ID.

Although the film leaves behind more questions than answers - hardly surprising bearing in mind the strict Iranian censorship - it is an inspiring essay on human dignity, solidarity and moral resilience, capable of transcending even the harshest social and political circumstances.

\section{As God Commands (Come Dio comanda)}

The Italian entry, As God Commands is an emotionally charged story of yet another contemporary quest or rather, a sentimental journey - of a father and his teenage son who rediscover each other after a series of disastrous events, culminating in the father's near fatal ailment. What is unusual in this rather intense, not to say hysterical, film is that its narrative falls neatly into two parts that are quite different, even contradictory ideologically and aesthetically. The first half, dominated by a very active plot, could be defined as a melange of Western European (if I may) 'miserabilism' and a horror flick. It introduces a father and son, living on the social and urban margins of a big city. The father is susceptible to white supremacist rant, and teaches his son how to shoot a gun; and how to hate Slavs and Arabs as villainous culprits since they are taking jobs away from native Italians like themselves. The son (very authentically represented by Alvaro Caleca), even writes an essay, praising Hitler for his policies against ethnic minorities to please his father. The chain of calamities is however initiated by a third character - the mentally challenged friend of the family who chases and accidentally kills an attractive teenage girl from the son's school. The father runs to the rescue but falls suddenly ill, and the son engages in an elaborate cover-up of the crime scene by hiding and then throwing the girl's corpse into a river in order to protect both his father and the insane perpetrator from the police.

The shorter second part is all about the bond of father and son. Dominated by excessive melodramatic passions and coincidences, it takes place mostly in the hospital - apart from some brief scenes with the already repentant killer. On the wings of their reinforced love, father and son eventually succeed in circumventing the forces of social evil - or what they have maybe mistakenly perceived as such before the initiating brush with death. The killer conveniently hangs himself so the two of them could now freely bask in the newly found meaning of life undisturbed by memories. One could only wish that the two parts of the film, defined in Geoffrey Nowell-Smith's terms as paradigms of 'doing' (the male action genres, like the thriller) and 'suffering' (the woman's film or melodrama), were blended in a potentially excellent male melodrama, based on 'suffering while doing... a saga about the painful destruction of the ego-ideal under the pressure of unpredictable social and political forces' (see G. Noel-Smith).

\section{Two Films in Minor Key}

\section{Burning Mooki (Mooki bo'era)}

The Israeli film Burning Mooki is also about a charged family relationship, this time between a mother and son. It is arguably the only film in competition without an explicit social or moral agenda, and features a protagonist who is not a victim of circumstance but of his own indocile emotions. Structured as an episodic stream-of-consciousness narrative, it evokes painful memories of Mooki's frustrated bildungs quest, which in psychoanalytical terms could be defined as a subjective rendition of a botched Oedipal trajectory - that is, the hero's account of his inability to extricate himself from the infantile attachment to his mother and mature as a replica of his father - seen through his own eyes.

The film opens with a phone call Mooki, an overweight and grumpy forty-something family man, receives in his Norwegian home, conveying the news of his mother's passing in far off Israel. This sad news triggers a flashback to his youth in the 1960s, when his parents and their friends - all Holocaust survivors - were still young and partying hard in an attempt to silence if not to heal their still fresh wounds and sense of agonizing guilt before the ones who never made it. The film is however about the young and slender Mooki and his attraction to his beautiful mother who, after the untimely death of his beloved father, somehow very quickly moves in with the bullish Yanek. Although it is tempting to quote here Hamlet bemoaning the 'salt of most unrighteous tears' in his mother's eyes while substituting his father, the King, with 'most wicked 
speed', Mooki's tragic downfall is much messier than Hamlet's straightforward demise.

All the more that Mooki's world is not populated as Hamlet's by clear-cut self-sacrificial friends and conniving enemies but by complex individuals, many of whom like Yanek are rumoured to have collaborated with the Nazis in order to survive. And yet it is Yanek whom his mother passionately loves and who, although well aware of Mooki's hatred, comes to his rescue at critical moments. Overwhelmed by jealousy and anger, the boy tries hard to strike on his own in love and life but gradually sinks deeper into self-hate and depression. One night, drunk and disguised in Nazi uniform, he breaks into his mother's home and rapes her, thus symbolically evoking the most horrific experience of her generation - the Holocaust. Convinced that it is all her fault, Mooki flees to Norway in the hopes that distance and time would dissipate the memory of her and of what he has done to her. Thus Mooki's decision to attend his mother's funeral in spite of the disturbed memories, lulled for so long amongst the reefs of his unconscious by denial and alcohol, wraps up nicely the frame narrative, but hardly provides a closure for his demon-ridden past.

Mooki's story of brave soul-searching resounds with a gripping energy maybe because such a confessional narrative about the arduous road to self-knowledge has become a rarity even within the confines of arthouse cinema, which tends - as eloquently illustrated by the competition program - to increasingly privilege circumstance over character, mythos over ethos, historical and social determinism over personal responsibility. And to ultimately construe the individual - in tune with our zeitgeist - as a helpless victim, therefore morally and rationally innocuous even when compromising her or his human integrity by choice.

\section{Five Days Without Nora (Cinco dias sin Nora)}

Before closing this rather lengthy observation of the $31^{\text {st }}$ Moscow IFF competition, a brief reference to the Mexican entry Five Days Without Nora is in order. Made by Mariana Chenillo, the youngest director in competition (born in 1977), this chamber film was one of the best crafted in the program, and in a way offered a refreshing, almost textbook counterbalance of the prevailing aesthetic and ethic penchants of the works discussed this far, focusing entirely on its protagonist's thorny path to forgiveness.

To begin with, the plot abides by the three classical dramatic unities, outlined by Aristotle - of action, time and place. The one main action of the plot is Jose's efforts to have his former wife buried. However, Nora has killed herself on the eve of Passover, so in accordance with the Judaic tradition, the funeral cannot take place until after the festivities - thence the eponymous violation of the unity of time principle, postulating that the action should take no longer than twenty four hours. The unity of place is strictly observed, though, and apart from a few digressions consisting mostly of Jose's flashbacks, the action takes place entirely in Nora's apartment.

The dynamics between incidents prompted by Nora's death and those initiated by the protagonist Jose a handsome elderly gentleman in the psychologically nuanced interpretation of the popular Mexican actor Fernando Luján - is also well observed. With their son and his family on vacation, the atheistic and somewhat reluctant Jose is the only one left in charge of the corpse and the funeral arrangements. Once alone in Nora's apartment, however, he quickly figures out that she has strategically ended her life on the eve of Passover. This realization sets him on an emotional roller-coaster: on one hand, his belief this is the last manifestation of his ex-wife's manipulative desire to keep him as close as possible triggers his angry decision to have her buried as rapidly as possible even if this has to be done according to the Catholic ritual. On the other hand, Nora's passing sets off a series of sentimental flashbacks of their tumultuous love-hate relationship spanning over thirty years, of her breakdowns, infidelities and insecurities, and of his dashed hopes and growing impatience with her and, consequently with his son and his urge to please everyone.

True to its classical humanist pedigree, however, the film raises its emotional stakes of pity and fear as Jose, humbled by the turmoil of painful revelations about his family's past and present, moves through sadness, dark irony, petulance, nostalgia, sarcasm and relieving laughter, enticing us along to his final cathartic revelation that - all the bitterness notwithstanding - Nora was the love of his life... Thus, without playing up the often didactic juxtaposition of social and historical circumstance vs. personal responsibility, or the game of blame and guilt, Five Days Without Nora quietly reminds us of John Milton's wisdom that

The mind is its own place and in itself, can make a Heaven of Hell, a Hell of Heaven... 


\section{References}

Aristotle's Poetics, trans. S. H. Butcher, introduction by Francis Fergusson (Hill \& Wang, 1961).

Frye, Northrop. 1957. Anatomy of Criticism (Princeton, NJ: Princeton UP, 1990, 34).

Nowell-Smith, Geoffrey. Minnelli and melodrama, in Christine Gledhill (ed.). Home is Where the Heart is: Studies in Melodrama and the Woman's Film (London: British Film Institute, 1987, 70-74).

Stojanova, Christina. "The Politics of Gender and Genre in Post-Communist Cinemas" in Traditions in World Cinema, Linda Badley, R. Barton Palmer, \& Steven Jay Schneider, Eds. (Edinburgh: Edinburgh University Press, UK, 2006, 103-107).

Stojanova, Christina, "A Gaze From Hell: Eastern European Horror Cinema Revisited" in European Nightmares, P. Allmer, D. Huxley and E. Brick, Eds., Wallflower, UK /Columbia U Press, USA (forthcoming).

\section{Author Information}

Christina STOJANOVA teaches at the Department of Media Production and Studies at the University of Regina, Canada. She has contributed to Cine-bulles, KinoKultura, and the Montreal Gazette. Her publications include chapters in Berlin Culturescapes, Making it Like a Man: Canadian Masculinities, Eastern European Cinema, Traditions in World Cinema, Horror International, Alternative Europe and Cinema and Globalization. 